\title{
Peran Komunitas Seni Dalam Mengembangkan Karya Hand Lettering Di Era Digital
}

\author{
Arifah Insani Sari Utami', Ahmad Adib², Sahid Teguh Widodo ${ }^{3}$ \\ Program Studi Magister Seni Rupa Universitas Sebelas Maret Surakarta \\ 'arifahinsanisu@gmail.com
}

Hand lettering merupakan seni menggambar huruf dengan teknik manual, menggunakan peralatan seperti kuas, kapur, pen, alat pahat, dan lain-lain. Di era digital karya hand lettering menjadi popular. Pembahasan mengenai hal tersebut tidak hanya berhenti pada persoalan perwujudan estetis sebuah karya seni tetapi juga pada ranah kehidupan masyarakatnya yaitu kehidupan sosial, ekonomi, dan budaya di era digital saat ini. Komunitas berperan penting dalam mengembangkan hand lettering karena memiliki kekuatan untuk mempengaruhi lingkungannya. Artikel ini bertujuan untuk menyajikan penelitian peran dan fungsi komunitas seni dalam mempengaruhi masyarakat untuk berkarya seni tradisional dan mengembangkan hand lettering menjadi industri kreatif. Penelitian menggunakan pendekatan kualitatif dan analisis data diskriptif kualitatif. Hasil penelitian menunjukkan bahwa komunitas berperan penting dalam penegembangan hand lettering di era digitaldengan memaksimalkan fungsi komunitas yaitu 1) sebagai komunikator untuk mentransfer nilai, ide, dan pengetahuan mengenai hand lettering kepada anggota dan masyarakat pendukungnya 2) sebagai sarana melakukan pendekatan secara emosional kepada masyarakat untuk mensosialisasikan seni hand lettering sehingga dapat mempengaruhi kebutuhan estetis dan perilaku masyarakat pendukungnya 3) sebagai wadah dan ruang untuk mengaktualisasikan diri dalam berkarya seni hand lettering.

Kata Kunci : hand lettering, komunitas seni, era digital, industi kreatif

\section{The Role of the Art Community in Developing Hand Lettering Work in the Digital Age}

Hand lettering is the art of drawing letters with manual techniques, using tools such as brushes, chalks, pens, chisel tools and so forth. In the digital era, hand lettering works become popular. The discussion on this matter does not only stop at the issue of the aesthetic manifestation of a work of art but also in the realm of the lives of its people, namely social, economic and cultural life in the current digital era. Communities play an important role in developing hand lettering because they have the power to influence their environment. This article aims to present research on the role and function of the art community in influencing the people in general to create traditional art and develop hand lettering into a creative industry. The study used a qualitative approach and qualitative descriptive data analysis. The results showed that communities played an important role in developing hand lettering in the digital era by maximizing community function, namely 1) as a communicator to transfer values, ideas, and knowledge about hand lettering to members and their supporting communities 2) as a means of emotionally approaching the community to socialize art of hand lettering so that it can affect the aesthetic needs and the behavior of supporters 3 ) as a forum and space to actualize themselves in the work of art of hand lettering.

Keywords: hand lettering, art community, digital era, creative industry

Proses Review : 1 - 20 Agustus 2019, Dinyatakan Lolos: 22 Agustus 2019 


\section{PENDAHULUAN}

Perkembangan teknologi berdampak bagi kehidupan masyarakat secara global tidak terkecuali bagi kalangan pembuat karya seni tulis (lettering) atau biasa disebut letterer. Perubahan budaya yang serba instan di era digital membuat desainer pemula maupun profesional beralih pada penggunaan alat digital dalam proses pembuatan karya lettering. Penggunaan alat digital dinilai lebih ekonomis, efektif, dan efisien. Hal tersebut mengakibatkan berkurangnya minat dalam mendesain tulisan secara manual dan pembuat karya seni tulis berpeluang dalam melakukan tindakan plagiasi. Disebutkan bahwa kemampuan pembuatan sketsa secara manual (freehand) merupakan hal yang mutlak dimiliki seorang desainer dikarenakan metode freehand merupakan cara bagi seorang desainer dalam mengembangakan gagasan dan kreativitasnya (Kusnaedi, 2014). Demikian pula orisinilitas dari sebuah karya digital lebih diragukan dibandingan manual karena teknologi memiliki sifat manipulatif dan netral yang berarti bahwa orang dapat dengan mudah menduplikasi karya orang lain. Sedangkan di sisi lain kebutuhan estetis masyarakat terhadap seni tidak dapat dibendung. Seni hadir karena tuntutan biologis, artinya secara biologis karya seni dilahirkan karena dalam fungsi biologis manusia tersedia sistem yang mendukung atau menyokong perwujudannya (Rohidi, 2011: 50). Selain itu, lettering merupakan bagian dari salah satu sub sektor industri kreatif di Indonesia. Bidang kreativitas lettering memiliki potensi untuk dikembangkan karena terbukti berabad-abad bahasa tulis merupakan alat komunikasi yang penting bagi kehidupan manusia. Perlunya mengembangkan industri kreatif tersebut diperkuat adanya dorongan pemerintah untuk menjadikan ekonomi kreatif sebagai penggerak perekonomian Indonesia di tahun 2025, maka pemerintah menekankan pada kemajuan industri kreatif di Indonesia yang diatur dalam UU No. 3 Tahun 2014 tentang Perindustrian - mendorong pengembangan industri kreatif Nasional, UU No 28 Tahun 2014 tentang Hak Cipta - memberikan perlindungan kekayaan intelektual bagi karya kreatif, dan UU No 7 Tahun 2014 tentang Perdagangan - Mendorong perdagangan produk berbasis ekonomi kreatif.

Semenjak didirikannya komunitas hand lettering Belmen ID di Jakarta pada tahun 2014 karya hand lettering semakin populer di Indonesia. Meskipun pembuatan karya seni dan desain lettering telah didominasi dengan teknik digital, peminat seni tulis dengan metode manual tersebut semakin bertambah. Seiring berjalannya waktu telah lahir komunitas-komunitas yang sama antara lain di Bandung yaitu Bandung Menulis, Yogyakarta yaitu Jogja Creatype, Solo yaitu Surakarya, Salatiga yaitu Salatype, dan kota lainnya. Fenomena tersebut membuktikan bahwa hubungan komunitas seni dengan kesenian merupakan simbiosis mutualisme. Dalam sistem simbol, kesenian digunakan secara selektif oleh masyarakat pendukungnya untuk berkomunikasi, melestarikan seni, menghubungkan pengetahuan, dan bersikap serta bertindak untuk memenuhi kebutuhan integratifnya yang bertalian dengan pengungkapan tuntutan akan keindahan itu (Rohidi, 2000: 10). Keberadaan komunitas menjadi sarana bagi masyarakat dalam upaya menjaga eksistensi kesenian, sarana bersosialisasi, dan sebagai wadah dalam pemenuhan kebutuhan estetis pada minat yang sama. Namun, di era digital menunjukkan bahwa komunitas juga memiliki potensi berkontribusi dalam pengembangan industri kreatif di Indonesia. Dengan adanya latar belakang di atas maka perumusan masalah dalam penelitian ini adalah bagaimana peran dan fungsi komunitas hand lettering dalam mempengaruhi masyarakat modern untuk berkreativitas dengan metode manual di era digital dan bagaimana mengembangkan potensi karya hand lettering menjadi kreativitas komersiil di industri kreatif. Sedangkan tujuan penelitian dibagi menjadi dua yaitu menganalisis peran dan fungsi komunitas hand lettering dalam mempengaruhi masyarakat modern untuk berkreativitas dengan metode manual di era digital dan mengetahui pengembangan potensi karya hand lettering menjadi kreativitas komersiil di industri kreatif. Manfaat penelitian ini dapat memberikan gagasan bagi masyarakat dalam mengembangkan potensi karya hand lettering sebagai salah satu sub sektor industri kreatif di Indonesia.

\section{METODE PENELITIAN}

Penelitan ini menggunakan pendekatan kualitatif dan bersifat diskriptif. Teknik pengumpulan data dilakukan dengan wawancara etnologi (mendalam) kepada informan yang dipilih secara purposive sampling, observasi dilakukan di lapangan dengan melibatkan diri dalam kegiatan komunitas hand lettering di Surakarta, dan pengumpulan dokumentasi untuk memperkuat data. Kemudian analisis data dilakukan dengan pendekatan pada keilmuan Sosiologi yaitu pemaparan teori dari Parsons mengenai hakikat sifat manusia dalam bertahan hidup. Teori Parsons digunakan untuk menelaah fenomena yang terjadi saat ini yaitu keberadaan komunitas seni yang berdampak pada perkembangan seni hand lettering di era digital. Pembahasan mengenai hal tersebut tidak terlepas dari sifat manusia dalam mempertahankan diri dari ancaman terhadap kehidupannya atau mengembangkan kehidupannya ke arah yang lebih bermartabat menyesuaikan dengan jaman di mana manusia tersebut hidup, termasuk dalam memenuhi kebutuhan integratifnya. Sama halnya peran sebuah komunitas dalam menyebar luaskan seni hand lettering dan melakukan kegiatan persuasif di masyarakat.

Hakikatnya gejala yang muncul pada penelitian seni dibagi menjadi dua arah yaitu pertama faktor intraestetik yang menunjuk pada benda atau fenomena sebagai bentuk ekspresi yang lazim. Kedua yaitu faktor ekstraestetik yang menunjuk pada latarbelakang, nilai-nilai, pengetahuan, kepercayaan, serta lingkungan yang turut mewarnai perwujudan karya tersebut (Rohidi, 2011: 53). Komunitas seni sebagai objek penelitian akan dikaji pada perannya dalam 


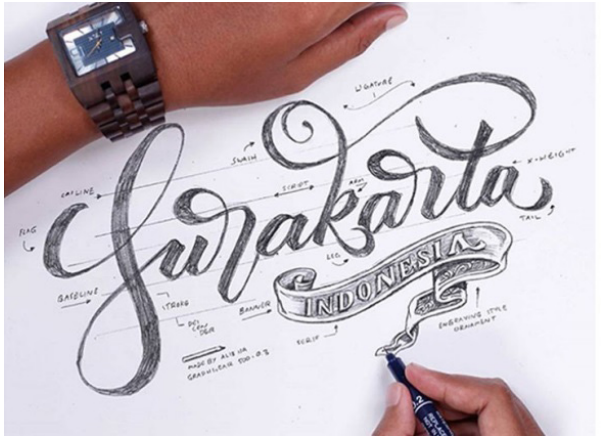

Gambar 1. Hand lettering sketch karya Alib Isa (Sumber: Instagram Alib Isa, 2018)

mempengaruhi masyarakat dalam berkesenian dan memberikan edukasi kepada masyarakat dengan merujuk pada teori Parson. Selain itu penelitian ini juga menggunakan pemaparan Arnold Hauser yaitu menentang seni modern yang bersifat mengisolasi, bahwa seni diciptakan hanya untuk individu sedangkan seni berangkat dari realitas sehingga seni merupakan produk massa. Teori tersebut digunakan untuk menganalisis realitas apa yang terjadi antara komunitas seni, produk seni, dan masyarakat masa kini. Sedangkan teori komunikasi menggunakan teori interaksi simbol George Herbert Mead yang memandang bahwa komunikator memberikan pemaknaan dalam interaksi, dalam hal ini komunitas sebagai komunikator yang melakukan komunikasi dengan masyarakat.

\section{ANALISIS DAN INTEPRETASI DATA}

Eksistensi seni hand lettering sebagai produk kreatif dan komunitas seni hand lettering di era digital

Sejak tahun 80-an seni hand lettering telah ada di Indonesia. Saat itu muncul tren penggunaan seni hand lettering pada kartu undangan dan souvenir. Namun kebiasaan menulis tangan tersebut mulai jarang ditekuni sejak adanya mesin ketik, komputer, dan gadget yang membuat proses menulis lebih praktis. Pada tahun 2014 semangat seni Hand Lettering di Indonesia mulai muncul kembali seiring dengan adanya semangat Do It Your Self dan seni crafting. Kecenderungan proses pembuatan karya dilakukan dengan cara tradisional. Di era yang serba digital atau mass media saat ini seni tradisional kembali dihidupkan. Pada dasarnya hal tersebut bukan sebuah perlawanan terhadap teknologi tetapi sebuah alternatif lain dalam proses berkarya di tengah persaingan industri kreatif dan memberikan peluang bagi dunia hand lettering untuk dikembangkan dalam komoditi industri kreatif. Di era digital saat ini seni hand lettering termasuk ke dalam seni kontemporer yang tergolong dalam popular art. Dijelaskan oleh Hauser (1982: 583) The fact that popular art, in contrast to the flexibility of high art, clings inflexibly to the rules, the standards of which seem to be the secret of best-sellers, hits, and smashes, is one of the most remarkable characteristics of this form of art. Sebagai karya seni kontemporer, seni hand lettering merupakan produk yang berangkat dari ke-

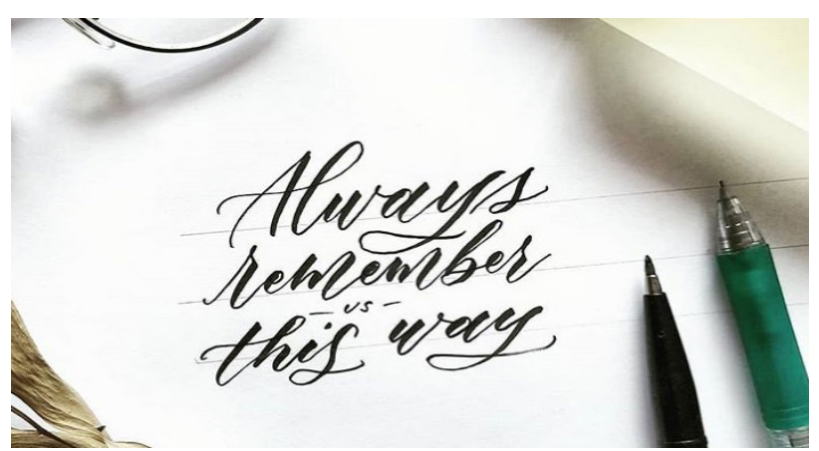

Gambar 2. Hand lettering karya Insannita M. S (Sumber: Instagram Insannita, 2018)

butuhan realitas masyarakatnya saat ini seperti pandangan Hauser yaitu seni merupakan produk sosial. Asal inspirasi atau ide seni bisa bersifat subjektif terbatas pada seniman saja tetapi produk keluaran yang dihasilkan bisa bersifat objektif sebagai bentuk komunikasi visual dan mampu memberikan implikasi terhadap audiens.

Dikemukakan oleh Suwarno (2006) bahwa seni kontemporer konsep dasarnya adalah upaya pembebasan dari kontrak-kontrak penilaian yang sudah baku atau mungkin dianggap usang. Sedangkan Arnold Hauser menjelaskan bahwa kreasi artistik seni tidak pernah menciptakan perwujudan yang asli atau benar-benar baru tetapi bentuknya selalu sarat dengan pertambahan, diperkaya, maupun disederhanakan dari bentuk yang telah ada (Hauser, 1982: 72). Begitu juga dengan seni hand lettering yang merupakan bentuk seni lama dianggap mampu menjadi terobosan bagi para seniman dalam berkarya melalui proses kreatif yang inovatif karena kejenuhan akan kemajemukan karya-karya digital yang ada saat ini. Dari hasil wawancara dengan salah satu founder Surakarya bahwa seni hand lettering memiliki nilai artistik tersendiri dibandingkan dengan tulisan komputer dan setiap letterer memiliki kekhasannya masing-masing. Dalam penelitian Aryo Sunaryo (2014: 137) dijelaskan bahwa penggunaan teknik freehand banyak membantu dalam mengembangkan keterampilan dan menyatakan pikiran dalam pencarian gagasan-gagasan secara konkret. Begitu juga dengan berkarya hand lettering, sensasi dan kemampuan yang digunakan berbeda jika dibandingkan dengan menggunakan huruf tamplete. Dalam proses perwujudan karya handlettering seniman atau desainer melalui tahapan pembuatan konsep bentuk huruf dengan manual skecting. Pada tahapan dasar tersebut diperlukan keahlian seniman dan desainer dalam membentuk struktur huruf yang estetis dan bernilai fungsi sehingga pesan dari tulisan dapat tersampaikan kepada audiens. Pada gambar 1 merupakan contoh konsep sketch karya Alib Isa. Tulisan "Surakarta" dibuat dengan konsep dasar kaligrafi modern. Penambahan bentuk flag, tail, swash pada huruf memberikan kesan nature pada tulisan tersebut. Sehingga perwujudan Surakarta yang identik dengan kota seni dan budaya tercerminkan pada typeface karya Alib Isa. 
Gaya yang ditampilkan oleh setiap kreator memiliki karakteristik masing-masing. Secara garis besar jenis huruf pada hand lettering berubah mengikuti perkembangan jaman. Meskipun demikian keanekaragaman bentuk huruf yang diciptakan dari masa ke masa tetap berporos pada bentuk-bentuk baku huruf di masa lampau. Dari jaman Yunani yang mengadopsi dari abjad Phonesia kemudian ditransformasikan menjadi Alphabhet, lalu huruf Romawi yang mengadopsi huruf Yunani dipadukan dengan tulisan Etruska yaitu tulisan Italia, kemudian huruf Old English yang banyak dijumpai pada kitab-kitab abad ke 19, hingga adanya gaya Bauhaus pada 1918 yang lahir di Jerman. Barulah kemudian jenis huruf hand lettering yang sedang tren saat ini mengacu pada jenis-jenis huruf di abad 19. Pada abad ke 19 jenis huruf yang diciptakan beranekaragam, jika merunut pada gaya Gothic jenis huruf dibagi menjadi 3 yaitu San-serif, Block-Letter, dan Contemporary (Sudiana, 2001: 327). Pada gambar 2 merupakan contoh karya seni hand lettering karya Insannita M. S yang diposting pada akun Instagramnya @insannita. Kekhasan pada karya Insannita yaitu penggunaan huruf jenis Contemporary yang mengacu pada style kaligrafi modern. Adapun penggunaan seni hand lettering yang diaplikasikan pada sebuah media sebagai penunjang elemen estetis, seperti mural di café, dekorasi ruangan, souvenir, merchendise, maupun pada iklan-iklan. Sebagai contoh pada gambar 3 yaitu mural hand lettering yang diaplikasikan pada dinding sebuah café.

Di era digital seni hand lettering tidak hanya berwujud goresan tinta di atas media kertas tetapi bertransformasi menjadi produk kreatif yang memiliki nilai fungsi. Hand lettering berkembang menjadi produk industri kreatif dan telah memiliki pasarnya. Terjadinya industrialisasi pada seni tentu dilatarbelakangi oleh beberapa penyebab. Pada penelitian sebelumnya dijelaskan oleh Ni Wayan Sukarini dkk (2018) bahwa penyebab terjadinya industrialisasi pada kasus seni kriya di Bali yaitu 1) adanya budaya massal ini disebut juga budaya popular yang diproduksi secara massal dengan wujud yang kreatif dan inovatif untuk memenuhi konsumsi masyarakat berdasarkan ideologi pasar 2) Kreativitas menciptakan seni kriya dengan paradigma baru yang merupakan respon dari keinginan pasar yang menghendaki adanya seni inovatif namun tetap memiliki nilai seni budaya masyarakat. Sehingga dari penelitian tersebut faktor konsumen dalam hal ini menciptakan permintaan pasar dan faktor produsen dalam berinovasi menjadi faktor yang penting untuk mewujudkan industrialisasi seni. Sedangkan menurut Figur (2015: 183) memandang seni sebagai sebuah produk multifungsi, menilai seni memiliki 3 fungsi yaitu fungsi sosial, fungsi personal, dan fungsi fisik. Pertama, fungsi personal, adalah adalah seni sebagai suatu alat mengekspresikan ide-ide, berkaitan dengan situasi yang mendasar, hubungan spiritual dan ekspresi estetis. Kedua, fungsi sosial, adalah bahwa karya seni itu memiliki fungsi sosial apabila karya seni itu mencari atau cenderung memengaruhi perilaku kolektif orang banyak,

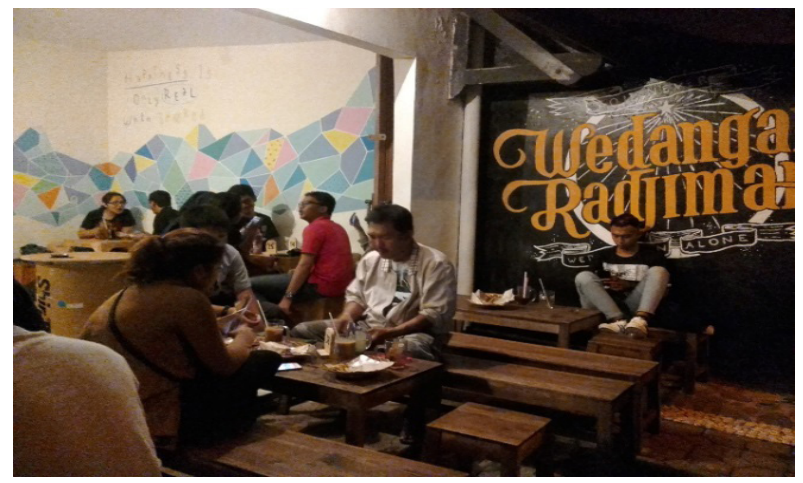

Gambar 3. Mural hand lettering di Wedangan Radjiman (Sumber: Instagram, 2017)

karya seni tersebut diciptakan untuk dilihat atau dipakai, digunakan khususnya dalam situasi-situasi umum, karya seni itu mengekspresikan atau menjelaskan aspek-aspek tentang eksistensi sosial atau kolektif sebagai lawan dari bermacam-macam pengalaman personal maupun individu. Ketiga, fungsi fisik, adalah suatu ciptaan objek-objek yang dapat berfungsi sebagai wadah atau alat. Contohnya visual hand lettering diaplikasikan menjadi desain pada berbagai macam merchandise yang memiliki nilai ekonomi, diaplikasikan pada dinding café atau ruang publik sebagai elemen desain interior maupun eksterior, dan ada beberapa workshop yang diadakan untuk pelatihan serta creative event lain.

Beberapa kota besar di Indonesia kini telah mendirikan komunitas hand lettering sebagai cabang dari induk komunitas Belmen ID yang berada di Jakarta, antara lain Surakarya di Kota Surakarta, Semarang Coret di Kota Semarang, Lettering Malang di Kota Malang, Bandung Menulis di Kota Bandung, Jogja Creatype di Kota Yogyakarta, Mbanjar Menulis di Kota Banjarnegara, Magelang Lettering di Kota Magelang, dan kota-kota lainnya yang berjumlah lebih dari 10 kota di Indonesia. Menurut Alib Isa (2018) sebagai salah satu pendiri komunitas hand lettering di Surakarta, tujuan didirikannya komunitas Surakarya yaitu untuk mewadahi kreativitas masyarakat dalam berkarya hand lettering, sebagai wadah dalam berbagi ilmu, serta sebagai upaya dalam mengembangkan eksistensi seni hand lettering di mayarakat terutama sebagai karya komersiil. Surakarya merupakan salah satu komunitas yang memiliki member tetap lebih dari 100 anggota. Beberapa event telah diadakan Surakarya yaitu Pen Meet Up, workshop, creative sharing, pameran, dan kegiatan sosialisasi seperti di CFD dan event lain. Dari hasil observasi dan wawancara bahwa masyarakat yang mulai menekuni bidang hand lettering tidak hanya dari kalangan pelajar maupun pekerja seni tetapi juga masyarakat umum yang memiliki ketertarikan terhadap seni tersebut.

\section{Seni hand lettering sebagai produk sosial masyarakat era digital}

Seni tidak hanya dipandang sebagai karya yang bersifat 


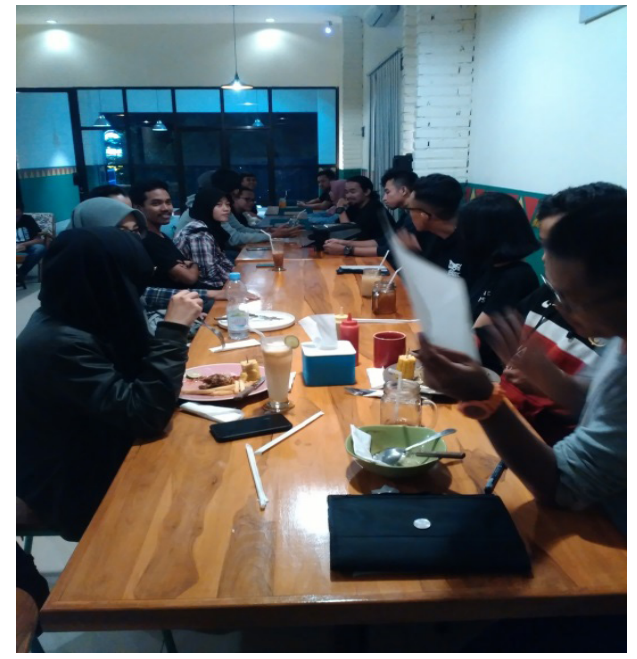

Gambar 4. Creative Sharing oleh komunitas Surakarya (Sumber: Dok Pribadi, 2018)

individualis tetapi juga dipandang sebagai produk sosial di masyarakat. Perwujudan seni sebagai satu kesatuan karya dapat merupakan bentuk ekspresi yang berdimensi individual, sosial, maupun budaya yang bermuatan isi sebagai substansi ekspresi yang merujuk pada berbagai tema, interpretasi, atau pengalaman hidup tertentu (Rohidi, 2011:52). Keberadaan sebuah karya seni harus dapat dirasakan kebermanfaatannya baik oleh seniman maupun masyarakat pendukungnya. Keberadaan seni popular hand lettering saat ini dilatar belakangi oleh kondisi sosio kultural masyarakat modern era digital. Adanya revolusi industri 4 berdampak pada kehidupan masyarakat baik pada aspek ekonomi, budaya, dan sosial. Pada aspek ekonomi, berdampak pada persaingan industri kreatif di era digital terutama dalam bidang desain grafis, membuat masyarakat harus melakukan sebuah terobosan baru dalam menciptakan karya maupun produk. Sebagai contoh komersialisasi pada karya hand lettering di antaranya dijadikan sebagai mural berfungsi sebagai elemen estetis ruangan café-café, dijadikan sebagai desain yang diaplikasikan pada $t$-shirt maupun merchandise lain. Aspek budaya, arus informasi yang dapat dengan mudah diterima oleh masyarakat seiring dengan berjalannya waktu mampu mengubah budaya masyarakat timur menjadi kebarat-baratan, di samping itu perubahan budaya masyarakat Indonesia di era digital ini cenderung konsumtif. Sedangkan aspek sosial, masyarakat tidak lagi mengandalkan kinerja individu dalam melakukan sebuah pekerjaan tetapi pekerjaan dilakukan secara team work. Selain itu adanya media sosial yang sedang berkembang saat ini mengubah pandangan masyarakat khususnya pengguna media jejaring sosial terhadap pencapaian dalam hidupnya yaitu menjadikan popularitas dan materi sebagai pencapaian utama dalam hidup.

Perkembangan jaman yang terjadi dalam kehidupan masyarakat akan menentukan pula bagaimana aktivitas masyarakat tersebut dalam berkarya dan mempertahankan hidupnya. Dapat diartikan bahwa wujud seni hand let- tering sebagai produk sosial dikarenakan oleh latar belakang keadaan ekonomi, sosial, dan budaya masyarakat di era digital yang terpengaruh oleh revolusi industri 4 . Masyarakat cenderung menyenangi kesenian yang bersifat modern, praktis dan menyenangkan, dibandingkan dengan kesenian tradisional daerah yang sarat akan makna, ritual dan membutuhkan ketekunan yang lebih dalam aktivitasnya. Meskipun demikian, merupakan fenomena yang unik ketika di era digital semakin banyak masyarakat yang berminat terjun ke dunia seni tulis manual tersebut. Berdasarkan penelitian banyak pegiat seni yang tertarik dengan karya tersebut dikarenakan ingin mencari pengalaman estetis yang berbeda dalam berkarya. Mengingat bahwa beberapa dekade belakangan ini teknologi digital telah menguasai dunia desain grafis, proses perwujudan karya dipermudah dengan sistem komputerisasi. Hal tersebut menyebabkan beberapa seniman atau desainer merasa kurang tertantang dan jenuh menggunakan media digital. Adapun berdasarkan hasil penelitian terdahulu, karya seni yang diproses secara manual juga memiliki beberapa kelebihan dibandingkan karya digital yaitu pengerjaannya lebih baik dalam hal intuisi, kreativitas, estetis, dan teknis (Kusnaedi, 2014: 108). Di samping itu, seni hand lettering tidak hanya difungsikan sebagai seni ekspresi yang hanya diperuntukkan memenuhi kebutuhan estetis saja, tetapi masyarakat pendukungnya telah melakukan komodifikasi seni hand lettering dikarenakan persaingan industri kreatif dan sebagai upaya dalam mengembangkan diri di tengah persaingan yang ada. Tidak hanya itu, adanya media sosial membuat masyarakat cenderung menjadikan seni hand lettering sebagai upaya untuk mendapatkan popularitas. Kondisi di atas menjelaskan bahwa munculnya kepopularan seni hand lettering saat ini dilatarbelakngi oleh gejala sosial yang ada di masyarakat saat ini.

Hakikat manusia dalam mengembangkan diri di lingkungan komunitas seni

Komunitas pada dasarnya merupakan sekelompok individu yang memiliki minat sama, terlibat dalam aksi yang sama dengan mengkoordinasikan peran masing-masing dan memiliki suatu tujuan yang sama. Komunitas harus memainkan peran dalam menyampaikan kekuatan seni dalam wacana yang kompleks sehingga dapat memperluas cakrawala yang menumbuhkan gagasan dari berbagai pendapat serta berperan membawa seni kepada khalayak publik (Pitts, 2012). Sedangkan komunitas seni yaitu komunitas yang terbentuk dari beberapa orang yang memiliki minat yang sama terhadap seni. Komunitas hand lettering merupakan komunitas yang terbentuk dari beberapa orang yang memiliki minat sama terhadap karya hand lettering. Setiap anggota terikat dalam sebuah sistem yang telah diatur dalam visi dan misi komunitas. Anggota yang tergabung dalam komunitas hand lettering memiliki latar belakang yang berbeda-beda baik dari segi profesi, pendidikan, dan lain-lain. Berdasarkan wawancara yang dilakukan terhadap anggota komunitas Surakarya, setiap anggota yang bergabung dalam komunitas Surakarya 
memiliki tujuan dan motivasi masing-masing untuk ikut bergabung dalam komunitas meskipun memiliki minat dan pandangan yang sama terhadap hand lettering. Ada yang bertujuan untuk membagikan ilmu, menjadikan wadah dalam berkesenian atau berekspresi, belajar hand lettering dengan baik dan benar, sekedar ingin tahu seni hand lettering, ingin berpartisipasi mengembangkan seni hand lettering, ingin mengembangkan karir, dan lain-lain. Meskipun tergabung dalam sebuah komunitas yang memiliki tujuan utama yaitu menghidupkan nilai seni, setiap individu akan berusaha mencapai sebuah tujuan masing-masing sebagai realitas personal, ada yang bertujuan sebagai pemberi dan ada yang bertujuan sebagai penerima.

Dijelaskan oleh Parsons bahwa perilaku yang dilakukan setiap individu selalu memiliki tujuan. Parsons mengemukakan bahwa hakikatnya manusia akan selalu melakukan 3 hal yaitu (1) manusia senantiasa berusaha untuk mengalihkan nilai-nilai, kepercayaan, dan pengetahuannya dari satu generasi kepada generasi lainnya, (2) nilai-nilai, kepercayaan, dan pengetahuan itu dipelajari, (3) nilai-nilai, kepercayaan, dan pengetahuan itu dihayati dan dimiliki bersama oleh para warga masyarakat pendukungnya (Parsons, 1951: 11). Hal tersebut menjelaskan bahwa dalam sistem kehidupan diperlukan pengalihan nilai-nilai, kepercayaan, dan pengetahuan untuk menjaga keseimbangan dalam hidup. Dalam hal ini terdapat dua individu yang memiliki peran berbeda yaitu sebagai pemberi (pendidik) dan sebagai penerima (peserta didik). Pertama, sebagai pendidik, manusia sebagai makhluk sosial manusia memiliki hasrat dan kebutuhan untuk melakukan interaksi sosial yaitu dengan mengalihkan nilai-nilai, kepercayaan, dan ilmu pengetahuan yang dihayati secara bersama dalam komunitas untuk memudahkan dan saling membantu dalam mencapai kesejahteraan secara bersama-sama. Kedua, sebagai peserta didik, manusia sebagai makhluk individu manusia membutuhkan nilai-nilai, kepercayaan, dan ilmu pengetahuan yang mana dijadikan sebagai alat untuk mengembangkan diri agar mampu bertahan hidup dan mencapai kesejahteraan. Sedangkan dalam buku Teori Komunikasi dijelaskan bahwa individu memiliki sifat-sifat dasar seperti 1) extraversion, kecenderungan untuk senang bergaul, menyukai kelompok lain, percaya diri, berpikir optimis 2) openness, kecenderungan untuk senang berpikir, memiliki daya imajinasi, memberikan perhatian, berpikir bebas 3) agreeableness, kecenderungan untuk menyukai atau bersimpati terhadap orang lain, suka membantu orang lain 4) sifat hati-hati kecenderungan sifat disiplin 5) neurotitisme, kecenderungan merasakan emosi negatif (Morrisan, 2015: 71). Sifat-sifat tersebut memberikan pengaruh terhadap aktivitas komunikasi yang terjadi dan pada akhirnya akan mempengaruhi proses pemenuhan kebutuhan setiap anggota dalam komunitas. Karena dalam sebuah sistem komunikasi individu memiliki peran sebagai komunikator dalam mentransfer ide, nilai, kepercayaan, dan ilmu pengetahuan kepada individu lain termasuk dalam hal berkesenian.

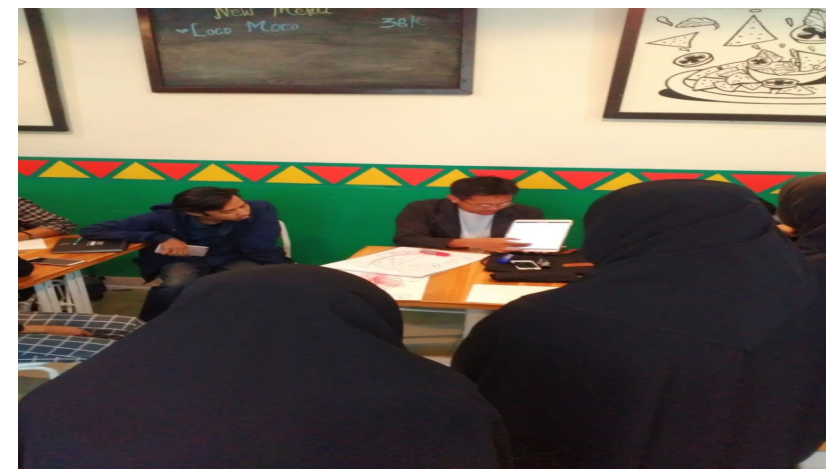

Gambar 5. Workshop oleh Alib Isa (Sumber: Dok Pribadi, 2018)

Dalam mengembangkan diri di bidang kesenian setiap individu membutuhkan pengakuan atau eksistensi diri dalam berkarya. Hal tersebut merupakan kebutuhan integratif yang mutlak dimiliki setiap manusia sebagai makhluk yang bermoral, berpikir, dan memiliki cita rasa. Perwujudan karya seni dipengaruhi oleh faktor latarbelakang, nilai-nilai, pengetahuan, kepercayaan, serta lingkungan yang turut mewarnai (Rohidi, 2011: 53). Seni bukan hanya dipandang sebagai wujud fisik tetapi jauh di dalamnya terdapat makna dan simbol yang menginterpretasikan fenomena dalam kehidupan sosial, budaya, ekonomi, politik, dan agama di lingkungannya. Adanya kebutuhan integratif tersebut menciptakan hubungan simbiosis mutualisme antara keberadaan komunitas dengan anggota-anggotanya. Anggota komunitas menjadikan komunitas seni sebagai wadah berekspresi estetik, mentransfer ilmu dan nilai-nilai seni melalui pendidikan, serta meningkatkan eksistensi diri dalam berkarya. Hubungan komunitas dan anggota komunitas merupakan simbiosis mutualisme. Fungsi komunitas berperan dalam proses pengembangan diri bagi setiap anggotanya. Tidak hanya pengembangan diri dalam hal yang bersifat fisik tetapi juga berkaitan dengan kebutuhan integratifnya termasuk kegiatan berkesenian. Dijelaskan Nooryan Bahari bahwa proses penciptaan atau kreasi karya seni dipengaruhi oleh faktor ekstraestetik yaitu faktor-faktor di luar bentuk fisik karya seni seperti faktor sosial, budaya, ekonomi, teknologi, religi, dan pendidikan dari seniman (Nooryan, 2014: 25). Dapat diartikan bahwa pada proses mengembangkan diri sebagai seorang praktisi seni hand lettering, dalam melakukan aktivitas perwujudan karya, anggota komunitas hand lettering akan memperoleh pengaruh dari lingkungan komunitas. Termasuk akan berpengaruh pada gaya perseorangan, tema yang akan dipilih, kreativitas tiap seniman, dan teknik yang digunakan dalam mewujudkan karya seni. Pada komunitas hand lettering setiap anggota bebas dalam berkreasi sesuai dengan minat dan gaya masing-masing. Nilai dan ilmu seni yang diberikan komunitas kepada anggota berfungsi untuk mengarahkan dan mengedukasi setiap anggota dalam mewujudkan karya secara baik dan benar. Selain itu, adanya interaksi yang terjalin antar anggota komunitas memberikan wawasan dan membuka jaringan pertemanan yang lebih luas, sehingga anggota terbantu untuk mengem- 
bangkan karirnya dalam bidang seni hand lettering.

\section{Peran komunitas seni mengembangkan hand lettering di masyarakat era digital}

Koentjaraningrat (2009: 65) membagi unsur-unsur kebudayaan menjadi tujuh aspek yaitu bahasa, sistem pengetahuan, organisasi sosial, sistem peralatan hidup dan teknologi, sistem mata pencaharian hidup, sistem religi, kesenian. Berarti bahwa pembahasan mengenai kesenian tidak dapat dilepaskan dari keadaaan sosial dan budaya masyarakat pendukungnya. Termasuk keberadaan komunitas seni hand lettering di era digital akan selalu terhubung dengan masyarakat dan keberadaan kesenian itu sendiri. Dalam hubungan tersebut terjadi sebuah komunikasi yang terkonsepsi dalam sebuah kebudayaan masyarakat era digital. Dapat dipahami bahwa dalam komunitas terbentuk sebuah pola komunikasi yang telah disepakati menjadi kode komunikasi bersama, begitu juga dengan komunitas seni hand lettering. Aktivitas komunikasi yang terjalin dalam komunitas merupakan sebuah upaya untuk mencapai tujuan secara bersama-sama dan menjaga keseimbangan sosial di dalamnya. Raymond Cattel menggunakan istilah sinergi bagi upaya yang dilakukan suatu kelompok untuk mencapai tujuan, sebagian energi digunakan untuk mengatasi hambatan kerja dan sebagian lagi digunakan untuk mengatasi hambatan interpersonal (Morrisan, 2013: 347). Salah satu tujuan dibentuknya komunitas hand lettering yaitu untuk menjaga nilai seni hand lettering serta mengembangkan potensi seni tersebut di masyarakat. Maka diperlukan sebuah kegiatan komunikasi antara komunitas dengan masyarakat dalam mensosialisasikan hand lettering. Komunitas berperan sebagai komunikator yang memberikan sebuah pemaknaan. Mengacu pada teori interaksi simbol George Herbert Mead bahwa komunitas seni memiliki kekuatan dalam menjaring masyarakat luas untuk ikut serta dalam kegiatan berkesenian yaitu dengan cara berinteraksi dan mendekatkan diri dengan masyarakat. Konsep interaksi simbolis menjelaskan bahwa makna sosial muncul karena adanya interaksi pada individu atau kelompok yang memiliki kedekatan dan emosional yang sama adalah yang dapat memberikan pengaruh kepada seseorang dalam bertindak dan melihat realitas (Morrisan, 2015: 112). Penjelasan tersebut menunjukkan bahwa dalam kegiatan persuasif dibutuhkan kedekatan dan emosional yang sama antara komunikator dengan objek. Komunitas hand lettering sebagai komunikator perlu melakukan pendekatan terhadap masyarakat secara emosional. Sehingga kedekatan komunitas dengan masyarakat dapat mempengaruhi pandangan masyarakat terhadap seni hand lettering dan pada akhirnya menumbuhkan minat masyarakat tehadap seni tersebut.

Pendekatan yang dilakukan komunitas seni hand lettering terhadap masyarakat pendukungnya lebih kepada pendekatan personal yaitu dengan melakukan kegiatan belajar menulis bersama seperti pen meet up, creative sharing, dan workshop yang dapat diikuti masyarakat pendukungnya dari berbagai latar belakang yang berbeda. Sedangkan pendekatan yang dilakukan kepada masyarakat secara meluas yaitu seperti mengadakan kegiatan tulis nama gratis pada acara Car Free Day atau kegiatan di universitas dan membuat karya hand lettering pada ruang publik. Salah satu bentuk pendekatan di ruang publik yaitu membuat karya mural pada dinding-dinding taman, café, creative space yang pada akhirnya mural tersebut dijadikan sebagai spot untuk berfoto masyarakat karena dianggap indah dan menarik. Selain itu kegiatan komunikasi juga dilakukan komunitas melalui media sosial, mengingat bahwa di era digital media sosial merupakan salah satu media yang efektif dalam menyebar luaskan informasi dan mempengaruhi perilaku audiens. Dalam penelitian Asep Wawan Jantika dan Ferry Fauzi Hermawan (2018:61) dengan judul Manjadi Lelaki Sejati: Maskulin Dalam Komik Daring Webtoon Indonesia dijelaskan bahwa internet dan media sosial menjadi salah satu media utama yang tepat dalam mengekspresikan dan menyebarluaskan karya komik. Dikarenakan penggunaan media tersebut lebih mendekatkan pembaca dengan komik, pembaca dapat mengakses kapan saja dan di mana saja. Sehingga dengan intensitas komunikasi yang lebih sering dapat pula mempengaruhi perilaku dan interaksi sosial penggunanya. Media sosial mampu menyuguhkan gambar maupun video secara jelas dan terinci kepada para pemakainya sehingga komunitas lebih mudah dalam menjalin interaksi dan mensosialisasikan seni hand lettering kepada masyarakat terutama masyarakat modern di era digital. Salah satu media sosial yang efektif digunakan saat ini adalah Instagram. Komunitas hand lettering juga menggunakan media sosial dalam penyebaran informasi salah satunya dengan akun Instagram komunitas Surakarya. Akun tersebut digunakan komunitas untuk menyebarkan informasi seputar hand lettering seperti jadwal event, karya-karya dari seniman hand lettering, dan kegiatan lain yang bersifat sosialisasi.

Pada penelitian sebelumnya dijelaskan bahwa komunitas memiliki beberapa fungsi yaitu sebagai jembatan ekspresi seni, sarana berkumpul dan merekatkan kembali serta melestarikan keberadaan seni yang ada di masyarakat (Pitaloka, 2017: 61). Komunitas hand lettering memiliki fungsi sebagai wadah dalam pemenuhan kebutuhan integratif masyarakat terutama untuk memenuhi kebutuhan estetis masyarakat modern. Selain menjadi wadah atau sarana dalam memenuhi kebutuhan estetis masyarakat modern, komunitas seni hand lettering juga menjadi sarana bagi masyarakat yang haus akan popularitas untuk mengaktualisasikan diri dan meningkatkan eksistensi diri ketika berkarya seni. Hal tersebut merupakan salah satu dampak dari penggunaan media sosial saat ini, yaitu masyarakat pengguna media sosial berlomba-lomba untuk eksis di media sosial. Maka dari itu peran komunitas dalam mengembangkan seni hand lettering sebenarnya tidak hanya terbatas pada pelestarian eksistensi seni tersebut. Dikarenakan dalam proses mengembangkan sebuah seni juga harus mempertimbangkan kondisi sosial budaya dan kebutuhan 
integratif masyarakatnya. Terdapat tiga faktor utama dalam mengembangkan seni hand lettering yaitu seniman, ruang, dan masyarakat pendukungnya. Pertama, seniman merupakan anggota-anggota komunitas itu sendiri, setiap anggota komunitas harus memiliki visi dan misi yang sama dalam mengembangkan seni. Kedua, ruang dibutuhkan oleh komunitas sebagai tempat dalam berekspresi dan mengembangkan seni. Ketiga, masyarakat pendukung merupakan masyarakat yang ikut berpartisipasi dalam kegiatan maupun masyarakat yang tertarik dengan seni hand lettering, minat dan antusiasme masyarakat terhadap seni sangat mempengaruhi perkembangan seni hand lettering. Sehingga dalam usaha mengembangkan seni hand lettering komunitas juga berperan dalam mendorong semangat anggotanya dalam berkarya, mensejahterakan setiap anggotanya, dan memberikan keseimbangan dalam sistem dengan cara mewadahi kebutuhan estetis masyarakat pendukungnya di era digital. Hal tersebut akan memberikan dampak yang positif terhadap pengembangan seni hand lettering di era digital.

\section{SIMPULAN}

Pembahasan mengenai kesenian tidak dapat dilepaskan dari keadaaan sosial dan budaya masyarakat pendukungnya. Perkembangan teknologi menyebabkan perubahan kehidupan sosial, ekonomi dan budaya masyarakat berubah, kemudian berpengaruh pada kebutuhan integratif termasuk di dalamnya terdapat kebutuhan estetis. Masyarakat modern cenderung menyenangi kegiatan berkesenian yang popular dan menyenangkan. Selain itu masyarakat modern juga mengalami persaingan industri kreatif yang lebih ketat. Sehingga diperlukan wadah bagi masyarakat untuk memenuhi kebutuhan tersebut yaitu dengan membentuk komunitas seni, salah satunya komunitas seni hand lettering. Keberadaan komunitas hand lettering pada dasarnya merupakan kumpulan dari beberapa individu atau orang yang memiliki minat yang sama terhadap seni hand lettering dan memiliki tujuan yang sama yaitu menghidupkan dan mengembangkan seni tersebut. Dalam mencapai tujuannya yaitu mengembangkan seni hand lettering, komunitas memiliki beberapa peran penting yaitu 1) sebagai komunikator untuk mentransfer nilai, ide, dan pengetahuan mengenai hand lettering kepada anggota dan masyarakat pendukungnya 2) sebagai sarana melakukan pendekatan secara emosional kepada masyarakat untuk mensosialisasikan seni hand lettering sehingga dapat mempengaruhi kebutuhan estetis dan perilaku masyarakat pendukungnya 3) sebagai wadah atau ruang untuk mengaktualisasikan diri atau wadah berkarya seni hand lettering. Sehingga dapat disimpulkan bahwa komunitas seni memiliki peran penting dalam mengembangkan karya hand lettering di era digital. Aktivitas persuasif yang dilakukan oleh komunitas dapat mempengaruhi minat dan antusiasme masyarakat modern di era digital terhadap seni hand lettering. Pada akhirnya keberadaan seni hand lettering di era digital dapat berkembang dan telah menyentuh ranah industri kreatif.

\section{DAFTAR RUJUKAN}

Bahari, Nooryan. (2014), Kritik Seni: Wacana, Apresiasi dan Kreasi. Pustaka Pelajar, Yogyakarta.

Hauser, Arnold. (1982), The Sociology of Art. University of Chicago Press, Chicago.

Koentjaraningrat. (2009), Pengantar Ilmu Antropologi. PT Rineka Cipta, Jakarta.

Morrisan. (2015), Teori Komunikasi Individu Hingga Massa. Kencana, Jakarta.

Rohidi, Tjetjep Rohendi. (2011), Metodologi Penelitian Seni. Cipta Prima Nusantara, Semarang.

Rohidi, Tjejep Rohendi. (2000), Kesenian Dalam Pendekatan Kebudayaan. STSI, Bandung.

Talcott, Parsons. (1951), The Social System. Free Press, New York.

Aryo Sunaryo. (Juli 2014), "Keanekaragaman Ungkapan Karya Sketsa Para Anggota Komunitas Indonesia's Sketcher", dalam IMAJINASI, Jurnal Seni, XIII/02, UNNES, Semarang.

Jatnika, A., \& Hermawan, F. (2018). Menjadi Lelaki Sejati: Maskulinitas Dalam Komik Daring Webtoon Indonesia. Mudra Jurnal Seni Budaya, 33(1), 60-66. https://doi. org/10.31091/mudra.v33i1.158

Dedi Sudiana. (Juni 2001), “Tipografi: Sebuah Pengantar”, dalam MEDIATOR, Jurnal Komunikasi, II/02, UNISBA, Bandung.

Figur Rahman Fuad. (April 2015), "Wayang Onthel Komunitas Old Bikers Velocipede Old Classic (VOC) Magelang”, Jurnal Kajian Seni, I/02, UGM, Yogyakarta.

Iyus Kusnaedi, Pribadi Widodo, Triyadi Guntur. (Desember 2014), "Hubungan Kemampuan Sketsa Freehand dan Digital dengan Kreativitas Mahasiswa dalam Proses Pendidikan Desain, Studi Kasus Mahasiswa Tingkat Akhir Desain Interior FSRD Itenas Bandung”, dalam REKARUPA, Jurnal Desain dan Seni Rupa, II/02, Itenas, Bandung.

Mayang Pitaloka. (Januari 2017), “Peran Komunitas Seni Rupa “ORArT-ORET” sebagai Wadah Ekspresi Seni Masyarakat Kota Semarang”, dalam IMAJINASI, Jurnal Seni, $\mathrm{XI} / 01$, UNNES, Semarang. 
Sukarini, N. W., Beratha, N. L. S., \& Rajeg, I. M. (2019). Industrialisasi Seni Kriya Di Desa Mas, Gianyar. Mudra Jurnal Seni Budaya, 34(1), 45-52. https://doi.org/10.31091/ mudra.v34i1.634

Suwarno Wisetrotomo. (10-14 November 2006), "Seni Rupa Kontemporer Indonesia: Ikhwal Estetika, Representasi, dan Merawat Kebudayaan", dalam Konferensi Estetika Internasional Asian Society of Art

Villa Prana Shanti, Bali.

Pitts, Phillippa. (30 Oktober 2012), What is the role of arts organizations in society \& their place in the community?. http://www.artsjournal.com

\section{Daftar Nara Sumber/Informan}

Somad, Abdullah (37), Hand lettering artist, Founder Komunitas Surakarya. Wawancara tanggal 15 Mei 2017 di Saffron, Surakarta.

Muti'ah S., Insannita (27), Hand lettering artist, Members Komunitas Surakarya. Wawancara tanggal 10 Desember 2017 di Conejo Mexican Fusion, Surakarta.

Soedarno, Hindi C., Hand lettering artist, Workshop Participant. Wawancara tanggal 20 Spetember 2017 di Arje's Kitchen, Suarakarta. 